Nig. J. Biotech. Vol. 38 (2) : 14-23 (Dec 2021)

ISSN: 01891731

Available online at

http://www.ajol.info/index.php/njb/index

and www.biotechsocietynigeria.org

DOI: https://dx.doi.org/10.4314/njb.v38i2.2

\title{
Effect of different extraction methods on micro-component composition and oxidative stability of oil produced from African pear (Dacryodes edulis) mesocarp Oil
}

\author{
${ }^{1}$ Onwuzuruike, U. A., Okakpu, C. J., ${ }^{1}$ Ndife J., Uzochukwu, U. C. and \\ 1 Ubochi, 0. \\ ${ }^{1}$ Department of Food Science and Technology, College of Applied Food Sciences and Tourism, Michael \\ Okpara University of Agriculture, Umudike, Abia State, Nigeria.
}

\begin{abstract}
Three different methods, including Soxhlet, traditional and screw press, were used to extract oil from African pear pulp. The oils were analysed for selected minerals and phytonutrients; stored for 4 weeks and analysed for oxidative changes. The microcomponents results ranged from 0.00 to $41.50 \%$ for chlorophyll, 0.00 to $1.25 \mu \mathrm{g} / 100 \mathrm{~g}$ for total carotenoids, 0.02 to $0.04 \mathrm{mg} / 100 \mathrm{~g}$ for iron, 0.00 to $0.01 \mathrm{mg} / 100 \mathrm{~g}$ for copper, and 18.25 to $208.50 \mathrm{mg} / 100 \mathrm{~g}$ for vitamin $\mathrm{E}$. The oxidative stability results showed that peroxide values ranged from 0.13 to $2.69 \mathrm{meq} \mathrm{O}_{2} / \mathrm{kg}$ in week 1 to 0.92 to $3.62 \mathrm{meq} \mathrm{O}_{2} / \mathrm{kg}$ in week 4; FFA ranged from 0.36 to $7.04 \%$ in week 1 to 0.39 to $11.47 \%$ in week 4; density ranged from 0.89 to $0.91 \mathrm{~g} / \mathrm{cm}^{3}$ in week 1 to 0.91 to $0.98 \mathrm{~g} / \mathrm{cm}^{3}$ in week 4; viscosity ranged from 17.17 to $51.57 \mathrm{RVU}$ in week 1 to 20.31 to $55.05 \mathrm{RVU}$ in week 4 and thiobarbituric acid level ranged from 0.02 to $1.11 \mathrm{mg} / \mathrm{g}$ in week 1 to 0.09 to $1.31 \mathrm{mg} / \mathrm{g}$ in week 4. Soxhlet extraction method produced oil of best quality with significantly ( $p<$ 0.05) higher mineral and phytonutrient contents, and of a longer storage stability
\end{abstract}

Keywords: African pear, mesocarp oil, oxidative changes.

*Corresponding author's Email: onwuzuruike.uzochukwu@mouau.edu.ng: +234(0) 8033981164.

\section{Introduction}

Vegetable oil is a valuable product of universal demand (Gayas and Kaur, 2017). It is composed largely of triglycerides (Nicholes et al., 2011). They are rich in essential fatty acids, provide energy and serve as a carrier of fat-soluble vitamins (Nayak et al., 2015). Aside their use for frying, in industrial and domestic food preparations (Falade et al., 2017), they are also used as major ingredient in the production of mayonnaises, shortenings and margarines. Oil seed crops such as groundnut, soybean, oil palm fruit, rapeseed and many more have been exploited for their lipid content (Ajala and Adeleke, 2014), while crops such as African pearare lesser known especially to the international community.

African pear is known in South-Eastern Nigeria as "ube" (Isaac and Ekpa, 2009). African pear fruits have seed that is enveloped or covered by a pulpy edible mesocarp, which is consumed either in its cooked or raw form (Sofowora, 2008). The fruit is made more palatable by softening the edible pulpy mesocarp in hot ash or hot water. The softened mesocarp may or may not be salted before being eaten as is as snack or with roasted, fried or boiled maize; and occasionally with bread, yam, soaked "garri" (cassava flakes), or cooked rice (Okeke et al., 2008). Its pulp is rich in oil, protein, fibre, minerals and essential amino acids (Onuegbu et al., 2016). The pulp and seed can be exploited for edible oils. The fresh mesocarp of African pear fruit contains about 26.73 to $35.05 \%$ oil (Nwosuagwu et al., 2009). Oil extraction from oil bearing mesocarp can be done with numerous methods such as solvent extraction, traditional and mechanical press (Alenyorege et al., 2015). According to Ikhuoria and Maliki 
(2007), oil extracted from African pear pulp contains palmitic oleic, stearic, and linoleic acids with values of $9.06 \%, 26.63 \%, 15.46 \%$ and $30.85 \%$ respectively. Antioxidant stability of extracted African pear mesocarp oil is of immense important as it influences its acceptability and market value ( $\mathrm{Hu}$ and Jacobsen, 2016; Almeida et al., 2017). Oxidative stability of edible oils can be accessed via multiple methods. Parameters such as free fatty acid value, para Anisidine value as well as peroxide value have been used for years to check oil stability during storage (Maszewska et al., 2018). Electronic methods involving Oven Test developed by Schaal known as Schaal oven test as well as Rancimat test are few of the major rapid test methods for testing oil stability as reported by Maszewska et al. (2018).

The dependence on conventional oilseeds like peanut seeds for vegetable oil production has resulted to oils with increased cost due to high demand of the oil products which eclipse production and supply. One of the major challenges in edible oil is the development of rancidity (oxidative) and deterioration of its quality due to environmental and storage conditions. Oxidation results in alteration of quality parameters and sensory properties. Such degradation, although relatively slow, may occur during heating and/or storage of the final product, thereby affecting its shelf life. Consumption of oxidized oil induces increased low-density lipoprotein (LDL), elevated cholesterol level and kidney malfunctioning (Falade et al., 2017). More so, there are limited studies on the oxidative stability of pear mesocarp oil. It is therefore important to conduct a research on the oxidative stability and minor components of African pear pulp oil extracted using different extraction methods. Findings of this research will reveal the most appropriate extraction method that would be most suitable for extracting the most stable pulp oil. This will add value to the fruit, increase varieties of edible plant oil market and may reduce cost. This may also lead to commercialization of the process for the pear oil; and on the long run benefit Nigeria.

\section{Materials and methods}

\section{Materials}

Mature, wholesome African pear fruits and soy oil (Golden Penny Nig. Ltd) were purchased from commercial stockers at Ubani Main
Market, Umuahia North Local Government Area, Abia State. The soy oil was labeled (SOY OIL) and used as a control.

\section{Methods} Preparation of African pear fruits for Soxhlet
extraction method.

Mature fruits of African pear were weighed (3 $\mathrm{kg}$ ) and undesirable ones were removed. The wholesome fruits were washed using clean tap water followed by extracting the seed after cutting open the fruit using a sharp kitchen knife. The hard mesocarp was diced $(2 \mathrm{~cm}$ wide) to aid fast and efficient drying at $65^{\circ} \mathrm{C}$ for $55 \mathrm{~h}$ in a hot air oven. The dried mesocarp was milled into coarse powder using an industrial attrition mill. The powder was packaged in an air-tight cellophane bag prior to extraction (Musa et al., 2012).

\section{Preparation of African pear for traditional and screw press extraction methods}

The method described by Adedokun and Onuegbu (2011) was modified and adopted for the preparation of African pear fruits before extraction. About $3 \mathrm{~kg}$ of African pear fruits were cleaned to remove unwholesome fruits. The fruits were washed using clean tap water then cut open with a knife to expose the seed for removal. The hard mesocarp were diced into $2 \mathrm{~cm}$ thick pieces before being packaged using an air-tight zip-lock low density polyethylene bags. The pulp was stored for 18 $\mathrm{h}$ at room temperature in a dark cupboard in order to ferment the hard mesocarp before extraction

\section{Extraction of oil from African pear mesocarp using Soxhlet extraction method}

African pear pulp oil was extracted using Soxhlet extraction method (Musa et al., 2012). First, n-Hexane $(250 \mathrm{ml})$ was introduced into a boiling flask (round bottom flask) followed by adding coarse African pear coarse mesocarp powder $(10 \mathrm{~g})$ into a thimble of the Soxhlet extractor. The thimble was plugged with cotton wool to prevent loss of sample to the solvent. The quick fit round bottom $500 \mathrm{ml}$ capacity flask containing the solvent was then connected to the soxhlet extractor. Water was allowed to flow through the reflux condenser via the pressure tap and the heating mantle was switched on. The set-up was heated to $50^{\circ} \mathrm{C}$ to reflux. The heat caused the solvent to vapourise through the thimble containing the sample as the solvent boiled in the flask; the 
vapour was trapped and cooled by the condenser above the thimble. The cooling turned the vapour into warm liquid which hydrolysed the sample in the thimble. When the thimble was filled with the drops of the warm solvent from the condenser, the solvent (which contained traces of the oil) was poured out into the flat bottom flask beneath the thimble containing either petroleum ether or isopropyl alcohol automatically through a siphon arm. The process was continued for the durations of $8 \mathrm{~h}$. At the end of each extraction process, the milled sample was removed from the thimble and the extraction process repeated, but this time for solvent recovery from the oil sample. This is done for an unspecified time depending on the quantity of oil and solvent contained in the flask from extraction. The oil was transferred into a beaker and placed on a steam bath, and finally dried in the oven for 30 minutes at $103^{\circ} \mathrm{Cto}$ evaporate residual solvent. The extracted oil was transferred into an amber bottle, labeled (SOXHLET) and stored in a refrigerator until used for analysis.

\section{Extraction of oil from African pear mesocarp using traditional extraction method}

Adedokun and Onuegbu (2011) described traditional method of extracting oil from African pear. This method was modified and adopted in this study. The softened mesocarp (3 kg) was introduced into a stainless bowl. Boiling tap water $(4000 \mathrm{ml})$ was added and manually stirred to enhance oil extraction and was left to stand for $5 \mathrm{~h}$. The liquid content was separated from the mixture using a clean kitchen sieve, transferred into a glass separating funnel, was allowed to stand for another $3 \mathrm{~h}$ to enhance separation of oil and water by gravity. The oil was collected by allowing the water to pass through the separating funnel by opening the funnel tap and closed back after the water completely flows out, leaving behind the oil. The oil was stored in amber coloured bottled, labeled (TRADITIONAL) and kept in a refrigerator until needed.

\section{Extraction of oil from African pear mesocarp using screw press extraction method}

The screw extraction method described by Adedokun and Onuegbu (2011) was adopted to extract oil from African pear mesocarp. The $18 \mathrm{~h}$ fermented mesocarp was weighed $(3 \mathrm{~kg})$ and introduced into a heating pan. The pan was heated using a heating mantle for 2 min set at $45^{\circ} \mathrm{C}$ to enhance oil extraction. The heated mesocarp was placed in a muslin cloth, tied properly and subjected to screw press to extract the oil. The oil was stored in amber coloured bottle, labeled (SCREW) and kept in the refrigerator

\section{Phytonutrient composition analysis}

Determination of chlorophyll and total
carotenoid content

The method described by Ankapong (2010) was used for the determination of chlorophyll and total carotenoid contents of the edible oil samples. Each oil sample $(100 \mathrm{ml})$ was mixed with $10 \mathrm{ml}$ of $80 \%$ acetone, and the mixture was centrifuged for 10 minutes. The supernatant was made up to $10 \mathrm{ml}$ using $80 \%$ ethanol. The absorbance was read at $480 \mathrm{~nm}$ for carotenoids, at $645 \mathrm{~nm}$, and $652 \mathrm{~nm}$ for chlorophyll in UV-vis spectrophotometer (Shimadzu UV-1800, Kyoto, Japan). Total chlorophyll and carotenoid contents were estimated in duplicate using the equations below:

$$
\begin{aligned}
& \begin{array}{l}
\text { Carotenoid content }=\frac{4 * \mathrm{~A}_{480} \mathrm{~nm} * \mathrm{~V} * 1000}{\text { Sample weight }} \\
\text { content }
\end{array} \\
& \begin{array}{l}
\text { Chlorophyll } \\
\frac{\left[20.2 *\left(\mathrm{~A}_{645} \mathrm{~nm}\right)+8.02 *\left(\mathrm{~A}_{663} \mathrm{~nm}\right) * \mathrm{~V}\right]}{1000 * \mathrm{~W}}
\end{array}
\end{aligned}
$$

Where $A$ : absorbance of specific wavelength, V: final volume of chlorophyll extract in $80 \%$ acetone, W: weight of the oil sample.

\section{Determination of vitamin $E$}

The vitamin E content was assessed according to Amankwa et al. (2009) method. One milliliter of each oil sample was weighed, mixed with $20 \mathrm{ml}$ of $\mathrm{n}$-hexane in a test tube for $10 \mathrm{~min}$ and centrifuged for another $10 \mathrm{~min}$. The solution was filtered, then $3 \mathrm{ml}$ of the filtrate was transferred into a dry test tube in duplicates and evaporated to dryness in a boiling water bath. Following this, $2 \mathrm{ml}$ of $0.5 \mathrm{~N}$ alcoholic potassium hydroxide was added and boiled for 30 minutes in a water bath. Then 3 $\mathrm{ml}$ of $\mathrm{n}$-hexane was added and was shaken vigorously. The $\mathrm{n}$-hexane was transferred into another set of test tubes and evaporated to dryness. Two milliliters of ethanol were added to the residue. A milliliter of $0.2 \%$ ferric chloride in ethanol was added. Then $1 \mathrm{ml}$ of $0.5 \%$ a1 a1-dipyridyl in ethanol was added followed by the addition of $1 \mathrm{ml}$ of ethanol to make it up to $5 \mathrm{ml}$. The solution was mixed and absorbance taken at $520 \mathrm{~nm}$ against the blank to obtain vitamin $E$ content of the oil samples. 


\section{Determination of mineral composition of the oils}

\section{Determination of iron}

Akintayor and Bayer (2002) method was adopted for iron content analysis. The oil sample $(2.5 \mathrm{ml})$ was pipette into a test tube in duplicate and $0.4 \mathrm{ml}$ of $5 \mathrm{~N}$ sodium hydroxide $(\mathrm{NaOH})$ was added to bring the $\mathrm{pH}$ at 4.0. Thereafter, $0.75 \mathrm{ml}$ of acetate buffer of $\mathrm{pH}$ $4.5,0.5 \mathrm{ml}$ of $25 \%$ hydroquinone, $0.5 \mathrm{ml}$ of $0.1 \% \mathrm{a}^{1} \mathrm{a}^{1}$ dipridyl was added as well as the addition of $0.35 \mathrm{ml}$ of distilled water to make it up to $5 \mathrm{ml}$. The absorbance was taken at 520 $\mathrm{nm}$ against the blank.

\section{Determination of copper}

The method described by Akintayor and Bayer (2002) was used in the determination of copper content of the edible oils. Two milliliters of each oil samples were preconcentrated on a hotplate before being dry ashed at $450^{\circ} \mathrm{C}$ for $2 \mathrm{~h}$ followed by dilution with distilled water. The ashed samples were allowed to cool at $24^{\circ} \mathrm{C}$ for $10 \mathrm{~min}$ in a dessicator. Five milliliters of mixture of $1 \mathrm{~N}$ nitric acid $\left(\mathrm{HNO}_{3}\right)$ and $10 \mathrm{ml}$ of $1 \mathrm{~N}$ hydrochloric acid $(\mathrm{HCl})$ was added to the ashed samples to form a solution. A reagent blank containing the acid mixtures used was prepared. The copper content of the oil samples was determined in duplicate using calibrated spectrometer (Model: GBC Avanta PM A6600) at $324.70 \mathrm{~nm}$ wavelength.

\section{Determination of oxidative stability}

The oxidative stability study was carried out for a period of 4 weeks. Each oil sample was divided into five (5) parts of $200 \mathrm{ml}$ and stored in an airtight bottle such that each bottle was withdrawn each week for analysis. The free fatty acid value, peroxide value, viscosity, thiobarbituric acid value and density (AOAC, 2010) of the oil samples were determined at the beginning and expiration of four weeks of storage.

\section{Statistical analysis}

Data were analysed using SPSS software version 21.0. The data were analysed using
Analysis of Variance (ANOVA), and means where significantly different at $p<0.05$ were separated using Duncan Multiple Range Test (DMRT) (SPSS 2018).

\section{Results and discussion}

Micro-components composition of the oil
samples

The micro-components composition of the oil samples is presented in Table 1. African pear mesocarp oil samples had higher chlorophyll content $(31.50-41.00 \%)$ than the control sample (SOYBEAN; $0.00 \%$ ). SCREW had the highest chlorophyll content (41.50\%), followed by TRADITIONAL (41.00\%). The presence of higher chlorophy11 content in SCREW and TRADITIONAL might be due to the fact that screw press and traditional extraction methods are not selective extraction methods which resulted to the extraction of all extractable component of oil seeds including chorophy 11 pigments. The high chlorophy11 content in crude African pear oils may affect their stability since chlorophyll has been reported to increase the rate of oxidation in edible oils (Akindele and Nsuhoridem, 2018). The absence of chlorophyll in SOYBEAN could be attributed to efficiency of refining towards the removal of pigments. More so, the presence of pigmentation in the. African pear pulp oil samples suggested the necessity of refining, specifically, bleaching.

The total carotenoid content of the oil samples ranged from 0.00 to $1.25 \%$. SOXHLET had the highest value while carotenoid content in SOYBEAN was not detected. The absence of carotenoid for SOYBEAN $(0.00 \mu \mathrm{g} / 100 \mathrm{~g})$ could be attributed to the refining process the oil was subjected to during processing. The high total carotenoid content recorded for African pear mesocarp oil samples suggested the possible presence of appreciable amount of $\beta$ carotene which has the capacity to slow down oil oxidation by light filtering, singlet oxygen quenching, sensitizer inactivation and free radical scavenging activity (Angaye and Maduelosi, 2015). 
Table 1: Micro-components composition of the oil samples.

\begin{tabular}{lccccc}
\hline Samples & $\begin{array}{c}\text { Chlorophyll } \\
(\%)\end{array}$ & $\begin{array}{c}\text { Total } \\
\text { Carotenoids } \\
(\mu \mathrm{g} / 100 \mathrm{~g})\end{array}$ & $\begin{array}{c}\text { Iron } \\
(\mathrm{mg} / 100 \mathrm{~g})\end{array}$ & $\begin{array}{c}\text { Copper } \\
(\mathrm{mg} / 100 \mathrm{~g})\end{array}$ & $\begin{array}{c}\text { Vitamin E } \\
(\mathrm{mg} / 100 \mathrm{~g})\end{array}$ \\
\hline SOXHLET & $31.50^{\mathrm{b}} \pm 0.71$ & $1.25^{\mathrm{a}} \pm 0.01$ & $0.04^{\mathrm{ab}} \pm 0.00$ & $0.00^{\mathrm{b}} \pm 0.00$ & $208.50^{\mathrm{a}} \pm 1.41$ \\
SCREW & $41.50^{\mathrm{a}} \pm 2.12$ & $1.17^{\mathrm{a}} \pm 0.01$ & $0.04^{\mathrm{ab}} \pm 0.00$ & $0.00^{\mathrm{b}} \pm 0.00$ & $201.00^{\mathrm{b}} \pm 0.71$ \\
TRADITIONAL & $41.00^{\mathrm{a}} \pm 1.41$ & $1.17^{\mathrm{a}} \pm 0.01$ & $0.04^{\mathrm{ab}} \pm 0.00$ & $0.00^{\mathrm{b}} \pm 0.00$ & $40.50^{\mathrm{c}} \pm 0.71$ \\
SOYBEAN & $0.00^{\mathrm{c}} \pm 0.00$ & $0.00^{\mathrm{b}} \pm 0.00$ & $0.02^{\mathrm{a}} \pm 0.01$ & $0.01^{\mathrm{a}} \pm 0.00$ & $18.25^{\mathrm{d}} \pm 0.07$
\end{tabular}

a-d: Values are means \pm standard deviation of duplicate determination. Mean values in the same column with different superscript are significantly different $(p<0.05)$.

The iron content $(0.02$ to $0.04 \mathrm{mg} / 100 \mathrm{~g})$ was not significantly different $(p>0.05)$ among the oil samples. The presence of transition metals such as iron is related to the oxidative stability of oils because of their catalytic effect on the decomposition of hydrogen peroxide. Metals have been reported to influence the speed of oxidative rancidity in oils because of their ability to lower the activation energy needed to activate the initial auto-oxidation process. Metals such as iron react directly with lipids to produce lipid alkyl radicals (Hosikian et al., 2011). The low iron content obtained for oil samples suggested that the iron content may not influence significantly their oxidation rate.

Similar to iron, copper is also a transition metal that increases the rate of oil oxidation in edible oil with a mechanism similar to that of iron and its presence increases oxidation rate (Choe and David, 2006) but 50 times faster than ferrous iron $\left(\mathrm{Fe}^{2+}\right)$ (Asuquo et al., 2012). From the results obtained in this study, the presence of copper was not detected in the oil samples under investigation and as such, would not be considered as a contributory factor to the oxidation rate of the oil samples.

The vitamin E obtained in this study showed significant differences among the oil samples with values ranging from $18.25 \mathrm{mg} / 100 \mathrm{~g}$ to $208.50 \mathrm{mg} / 100 \mathrm{~g}$. The African pear mesocarp oil samples had higher tocopherol content $(40.50-208.50 \mathrm{mg} / 100 \mathrm{~g})$ than SOYBEAN $(18.25 \mathrm{mg} / 100 \mathrm{~g})$. SOXHLET had the highest value of vitamin $E(208.50 \mathrm{mg} / 100 \mathrm{~g})$, followed by SCREW $(201.00 \mathrm{mg} / 100 \mathrm{~g})$. The low value obtained for SOYBEAN could be attributed to the refining process it was subjected to. The higher vitamin $\mathrm{E}$ content in the African pear mesocarp oil samples might impact better oxidative stability since vitamin E (tocopherol) has been reported to increase the oxidative stability of edible oils (Asuquo et al., 2012).

\section{Fresh oil samples}

The fresh oil samples prior to storage at room temperature is presented in Table 2 . The peroxide value ranged from 0.13 to 2.69 meq O2/kg with SOXHLET having the highest value while SOYBEAN (control sample) had the lowest value. Peroxide value provides information on the freshness of edible oils (Atinafu and Bedemo, 2011) during storage. High peroxide value is an indication of poor oil quality status. However, in some instances, low peroxide value could be an indication of advanced rate of oxidation due to condensation of hydrogen peroxides to form secondary oxidation product, resulting to their reduced quantity in the oil (Atinafu and Bedemo, 2011). This might be the reason for the low peroxide value observed in TRADITIONAL and SCREW. There were significant differences $(p<0.05)$ in the peroxide values of African pear mesocarp oil samples which suggested that, the different extraction methods had effect on their freshness. The effect of extraction methods on oil freshness might be due to the different extraction conditions associated with each method. Soxhlet method is selective in nature such that it extracts only the lipid content of the food material with reduced impurity and contamination. Traditional and screw are nonselective and extract all solvent-extractable components in the food material, thereby extracting pigments like chlorophyll, fatty acids like phosphatidic acid that promotes the formation of primary oxidation products. According to the CODEX Alimentarius standard for vegetable oil, the maximum allowable limit for peroxide value of crude and refined 
vegetable oils is 10 meq $\mathrm{O}_{2} / \mathrm{kg}$ fat (CODEX,

oil samples are fresh. 2011). It could therefore, be inferred that the

Table 2: Oxidative changes of African pear mesocarp oils extracted with different extracting methods during storage.

\begin{tabular}{lccccc}
\hline Samples & $\begin{array}{c}\text { Peroxide } \\
\text { value } \\
\left(\text { meq O}_{2} / \mathrm{kg}\right)\end{array}$ & $\begin{array}{c}\text { Free fatty } \\
\text { acid } \\
(\%)\end{array}$ & $\begin{array}{c}\text { Density } \\
\left(\mathrm{g} / \mathrm{cm}^{3}\right)\end{array}$ & $\begin{array}{c}\text { Viscosity } \\
(\mathrm{RVU})\end{array}$ & $\begin{array}{c}\text { Thiobarbituric } \\
\text { acid } \\
(\mathrm{mg} / \mathrm{g})\end{array}$ \\
\hline
\end{tabular}

\section{Fresh}

$\begin{array}{llllll}\text { SOXHLET } & 2.69^{\mathrm{a}} \pm 0.01 & 5.12^{\mathrm{b}} \pm 0.01 & 0.89^{\mathrm{d}} \pm 0.01 & 17.17^{\mathrm{d}} \pm 0.01 & 0.77^{\mathrm{c}} \pm 0.01 \\ \text { SCREW } & 1.81^{\mathrm{b}} \pm 0.01 & 7.04^{\mathrm{a}} \pm 0.01 & 0.91^{\mathrm{a}} \pm 0.01 & 17.35^{\mathrm{c}} \pm 0.01 & 1.08^{\mathrm{b}} \pm 0.01 \\ \text { TRADITIONAL } & 0.94^{\mathrm{c}} \pm 0.01 & 2.12^{\mathrm{c}} \pm 0.01 & 0.90^{\mathrm{b}} \pm 0.01 & 18.21^{\mathrm{b}} \pm 0.01 & 1.11^{\mathrm{a}} \pm 0.01 \\ \text { SOYBEAN } & 0.13^{\mathrm{d}} \pm 0.01 & 0.36^{\mathrm{d}} \pm 0.01 & 0.90^{\mathrm{c}} \pm 0.01 & 51.75^{\mathrm{a}} \pm 0.07 & 0.02^{\mathrm{d}} \pm 0.00\end{array}$

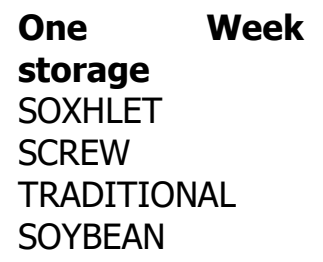

$\begin{array}{ll}2.97^{\mathrm{a}} \pm 0.01 & 7.07^{\mathrm{b}} \pm 0.01 \\ 1.93^{\mathrm{b}} \pm 0.01 & 7.64^{\mathrm{a}} \pm 0.01 \\ 1.04^{\mathrm{c}} \pm 0.01 & 3.34^{\mathrm{d}} \pm 0.01 \\ 0.15^{\mathrm{d}} \pm 0.01 & 0.38 \mathrm{c} \pm 0.01\end{array}$

$0.90^{\complement} \pm 0.00$

$18.06^{\mathrm{d}} \pm 0.01$

$0.81^{\mathrm{c}} \pm 0.01$

$0.93^{\mathrm{a}} \pm 0.00$

$18.67^{\circ} \pm 0.01$

$1.10^{\mathrm{b}} \pm 0.01$

$0.92^{\mathrm{b}} \pm 0.00$

$18.90^{\mathrm{b}} \pm 0.01$

$1.15^{\mathrm{a}} \pm 0.01$

$0.90^{\mathrm{d}} \pm 0.00$

$52.30^{\mathrm{a}} \pm 0.14$

$0.02^{\mathrm{d}} \pm 0.00$

\section{Four Weeks \\ storage \\ SOXHLET}

SCREW

$3.62^{\mathrm{a}} \pm 0.02 \quad 11.47^{\mathrm{a}} \pm 0.37$

$0.92^{c} \pm 0.01$

$20.53^{\mathrm{b}} \pm 0.01$

$1.03^{\mathrm{b}} \pm 0.01$

TRADITIONAL

$1.36^{\mathrm{b}} \pm 0.01 \quad 9.04^{\mathrm{b}} \pm 0.01$

$0.98^{\mathrm{a}} \pm 0.01$

$20.31^{\mathrm{b}} \pm 0.01$

$1.31^{\mathrm{a}} \pm 0.02$

SOYBEAN

$1.38^{\mathrm{b}} \pm 0.01$

$6.64^{\mathrm{c}} \pm 0.01$

$0.96^{\mathrm{b}} \pm 0.01$

$20.41^{\mathrm{b}} \pm 0.01$

$1.28^{\mathrm{a}} \pm 0.01$

$0.92^{\mathrm{c}} \pm 0.02 \quad 0.39^{\mathrm{d}} \pm 0.01$

$0.91^{\mathrm{d}} \pm 0.01 \quad 55.05^{\mathrm{a}} \pm 0.35$

$0.09^{\circ} \pm 0.00$

$\mathrm{a}-\mathrm{d}$ : Values are means \pm standard deviation of duplicate determination. Mean values in the same column with different superscript are significantly different $(p<0.05)$.

The value of free fatty acid (FFA) is used to ascertain the quality of edible oils. High content of FFA in edible oils is undesirable since its presence increases the diffusion rate of oxygen, which in-turn, increased the rate of oxidation. FFA values ranged from 0.36 to $7.04 \%$ with significant differences $(p<0.05)$ existing among the oil samples. These values were higher than the Codex Alimentarius Commission recommended value of 0.05 to $0.50 \%$ (CODEX, 2011) except SOYBEAN which suggested that the oil samples may undergo faster oxidation when exposed to undesirable storage conditions. More so, the high FFA present in African pear mesocarp oil samples may be as a result of cell degradation during size reduction (Atinafu and Bedemo, 2011), suggesting the need for refining process since the initial quality with respect to FFA is poor.

The value of density in edible oils is crucial in evaluating the suitability of such oils for frying. It dictates the extent to which the oil can drain after frying as well as the speed of cooling after frying with respect to the extent and rate of mass transfer. The higher the density, the slower the mass transfer rate of the oil during frying (Mengistie et al., 2018). The initial oil density of the oil samples from 0.89 to 0.91 $\mathrm{g} / \mathrm{cm}^{3}$ with significant differences $(P<0.05)$ existing among the oil samples. SCREW had the highest value $\left(0.91 \mathrm{~g} / \mathrm{cm}^{3}\right)$ while SOXHLET $\left(0.89 \mathrm{~g} / \mathrm{cm}^{3}\right)$ had the lowest value. The results indicated that processing had significant effect on the density of the oil samples. Edible oils with higher density, have slower mass transfer rate which makes them unsuitable for frying operations. The results of the African pear mesocarp oil are quite low may be suitable for frying operations (Dianet al., 2017).

Viscosity of edible oil is defined as oil's resistance to shear. Viscosity is affected by the degree of unsaturation and fatty acids chain length. A longer carbon chain and a decreasing degree of unsaturation results in an increase in viscosity (Hoekman et al., 2012; Pandurangan et al., 2012). Edible oils with high viscosity takes longer time to drain after frying. The initial viscosity of the oil samples ranged from 
17.17 to 51.75 RVU. SOYBEAN had higher value than African pear mesocarp oils. Higher viscosity in SOYBEAN suggested that African pear oils may have better absorption and drainability.

Thiobarbituric acid (TBA) value is an indication of the presence and level of oxidation products. The values were significantly different $(p<0.05)$ among the oil samples. The values ranged from $0.02 \mathrm{mg} / \mathrm{g}$ to $1.11 \mathrm{mg} / \mathrm{g}$. African pear oils had higher TBA than SOYBEAN $(0.02 \mathrm{mg} / \mathrm{g})$. SOXHLET had the lowest TBA value $(0.77 \mathrm{mg} / \mathrm{g})$ compared to other African pear oils which suggested lower rate of deterioration and as well, may substantiate the reason why SCREW and TRADITIONAL oil types had lower peroxide values. The higher TBA levels in the African pear oil samples may be due to the presence of higher concentration of malondialdehyde, a secondary oxidation product of oxidation.

Oxidative stability of the oil samples at the first week of storage (week 1)

The oxidative stability of the oil samples at the first week of storage is presented in Table 2. Peroxide value (PV) at one week after storage ranged from 0.15 to 2.97 meq $\mathrm{O}_{2} / \mathrm{kg}$ and was higher than those of the fresh oil quality assessment (0.13-2.69 meq $\left.\mathrm{O}_{2} / \mathrm{kg}\right)$, which indicated the possible progress of primary oxidation. SOXHLET had the highest PV (2.97 meq $\mathrm{O}_{2} / \mathrm{kg}$ ) while SOYBEAN had the lowest peroxide value $\left(0.15\right.$ meq $\left.\mathrm{O}_{2} / \mathrm{kg}\right)$. Higher peroxide value in SOXHLET implied the presence of higher amount of hydrogen peroxides. However, the PV of the oil samples after one week of storage are below the CODEX recommended limit, 10 meq $\mathrm{O}_{2} / \mathrm{kg}$ fat(CODEX, 2011), for edible oils, hence, the oils samples may be considered as being fresh.

The free fatty acid (FFA) value of edible oils is likely to increase during storage and transportation, depending on the conditions which influences the initial level of FFA (Gupta., 2002). Free fatty acid of the oil samples ranged from 0.38 to $7.64 \%$ after one week of storage; this was higher than the ( 0.36 to $7.04 \%$ values recorded in the fresh oil immediately after extraction. The increased FFA signified an increase activity of lipases coming from the source (Atinafu and Bedemo, 2011), which also suggested the increased occurrence of lipid oxidation.
The density of the oil samples after one week of storage ranged from 0.90 to $0.93 \mathrm{~g} / \mathrm{cm}^{3}$, with significant differences $(p<0.05)$ existing among the oil samples. SCREW had the highest value of density $\left(0.93 \mathrm{~g} / \mathrm{cm}^{3}\right)$, followed by TRADITIONAL $\left(0.92 \mathrm{~g} / \mathrm{cm}^{3}\right)$ while the lowest value was recorded in SOYBEAN and SOXHLET $\left(0.90 \mathrm{~g} / \mathrm{cm}^{3}\right)$. Notably, the density of the oil samples increased with storage time which implies changes in the chemical composition of the oil samples due to possible occurrence of oxidation.

Viscosity of oil has a direct relationship with degree of unsaturation and chain length of the fatty acids. Its value increases with increasing degree of saturation (Almeida et al., 2019). Viscosity of the oil samples after one week of storage ranged from 18.06 to $52.30 \mathrm{RVU}$. Similar to density, the viscosity values recorded after one week of storage were higher than the values recorded in the fresh oils. SOXHLET had the lowest value of viscosity (18.06 RVU) while SOYBEAN had the highest value of viscosity.

The results of thiobarbituric acid value ranged from $0.02 \mathrm{mg} / \mathrm{g}$ in SOYBEAN to $1.15 \mathrm{mg} / \mathrm{g}$ in TRADITIONAL. African pear oils had higher thiobarbituric acid value compared to the control (SOYBEAN; $0.02 \mathrm{mg} / \mathrm{g}$ ). These results showed significant increase from the values recorded after one week of storage (0.02-1.11 $\mathrm{mg} / \mathrm{g}$ ). The higher TBA levels in the African pear mesocarp oil samples is an indication of higher concentration of malondialdehyde, a secondary oxidation product.

\section{Oxidative changes in the oil samples at the fourth week of storage}

The oxidative stability of the oil samples after four weeks of storage is presented in Table 2. The peroxide value of the oil samples ranged from 0.92 to $3.62 \mathrm{meq} \mathrm{O}_{2} / \mathrm{kg}$. The values obtained showed consistent increase during storage but were below the CODEX maximum limit (10 meq $\mathrm{O}_{2} / \mathrm{kg}$ ) for edible oils and may still be considered to be fresh and acceptable after four weeks of storage.

FFA of the oil samples after four weeks of storage ranged from 0.39 to $11.47 \%$, with significant differences $(p<0.05)$ existing among samples. The values showed that the FFA increased steadily during storage. Furthermore, the FFA values of African pear mesocarp oils at the end of storage exceeded the maximum value $(0.05$ to $0.5 \%)$ 
recommended by the Codex Alimentarius Commission (CODEX, 2011) and may not be suitable for direct consumption.

The density of the oil samples after four weeks of storage ranged from 0.81 to $0.98 \mathrm{~g} / \mathrm{cm}^{3}$. There was significant increase $(p<0.05)$ after four weeks of storage compared to the value obtained for fresh oils which might be an indication of the occurrence of oxidation. The values obtained for SOXHLET $\left(0.92 \mathrm{~g} / \mathrm{cm}^{3}\right)$ and SOYBEAN $\left(0.91 \mathrm{~g} / \mathrm{cm}^{3}\right)$ were within the recommended value stipulated by $\mathrm{FAO} / \mathrm{WHO}$ $\left(0.919-0.925 \mathrm{~g} / \mathrm{cm}^{3}\right)$ for frying and cooking oils (CODEX, 2011) for density, while SCREW (0.98 $\left.\mathrm{g} / \mathrm{cm}^{3}\right)$ and TRADITIONAL $\left(0.96 \mathrm{~g} / \mathrm{cm}^{3}\right)$ had higher values after four (4) weeks of storage. It can therefore be implied that, among the extracted oil samples, SOXHLET (oil extracted through sohxlet extraction) may still possess properties suitable for domestic and industrial applications after four weeks of storage at room temperature (Dian et al., 2017).

Viscosity of the oil samples after four weeks of storage ranged from 20.31 to 55.05 RVU. Notably, the results for viscosity increased steadily from the values obtained for fresh oils to the values obtained after four weeks of storage in all samples with no significant differences existing among the oil samples (SOXHLET, SCREW and TRADITIONAL) after the storage period. The increased viscosity might be attributed to the impact of deterioration caused by oxidative processes.

Thiobarbituric acid number of the oil samples after four weeks of storage ranged from 0.09 to $1.31 \mathrm{mg} / \mathrm{g}$. There were no significant differences $(p>0.05)$ between SCREW and TRADITIONAL. The steady increase in the results after four weeks of storage may be attributed to increase formation of secondary oxidation products as a result of condensation of hydrogen peroxides (a primary oxidation products). Notably, among the extracted oil samples, SOXHLET had the lowest thiobarbituric acid value compared to SCREW and TRADITIONAL which suggested better stability and good quality of sample at the end of storage. The higher thiobarbituric acid value of SCREW and TRADITIONAL could be attributed to the increase condensation of primary oxidation products, which might be the reason SCREW and TRADITIONAL had lower peroxide value after four weeks of storage (Atinafu and Bedemo, 2011).
This study showed that SOXHLET had better micro-component composition and initial quality. During the four weeks storage period, the oxidative parameters increased steadily, with SOXHLET having the best oxidative stability than SCREW and TRADITIONAL. The peroxide value and TBA value did not exceed the CODEX maximum limit at the end of storage across all samples, while the FFA values exceeded the CODEX maximum limit. The presence of significant amount chlorophyll and high FFA values suggest the necessity of refining.

\section{References}

Adedokun, I. I. and Onuegbu, N. C. (2011). The physical properties of pulp and chemical characteristics of edible oil extracted from the pulp of African pear (Dacryodes edulis).

Pakistan J. of Nutr. 10(6): 558-560.

Ankapong, E. (2010). The influence of physicochemical characteristics of vegetable oils on the quality of biodiesel produced from palm oil, palm kernel oil, refined soyabean oil, unrefined soyabean oil and Jatropha curcasoil.A thesis submitted to the school of graduate studies, Kwame Nkrumah University of Science and Technology, Kumasi. Pp. 133136.

Ajala, A. S. and Adeleke, S. A. (2014). Effect of drying temperatures on physicochemicalproperties and oil yield of African star apple (Chrysophyllumalibidum) seeds. Global J. of Engr., Design and Tech.3(3):12-16.

Akindele, F. A. and Nsuhoridem, I. J. (2018). Extraction of vegetable oils from agricultural materials: A Review. Proceedings of the 12th CIGR Section VI International Symposium, held at the International Institute of Tropical Agriculture, Ibadan, Oyo State, Nigeria, 22-25 October, 1185-1206

Akintayor, E. T. and Bayer, E. (2002). Characterisation and some possible uses of Plukenetia conophora and Adenopusbreviflorus seeds and seed oils. Bioresource Tech. 85: 95- 97.

Alenyorege, E. A., Hussein Y. A. and Adongo T. A. (2015). Extraction yield, efficiency and loss of the traditional hot water floatation (HWF) method of oil extraction from the seeds

\section{Conclusion}


of Allanblackia floribunda. International J. Sci. Tech. Res.,4(2): 50-59.

Almeida, D. T., Curvelo, F. M., Costa, M. M., Viana, T. V. and Lima, P. C. (2017). Oxidative stability of crude palm oil after deep frying akara (Fried Bean Paste). Food Sci.

Tech. (Campinas), 38(1): 142-147.

Almeida, D. T., Viana, T. V., Costa, M. M., Silva, C. S. and Feitosa, S. (2019). Effects of different storage conditions on the oxidative stability of crude and refined palm oil, olein and stearin (Elaeisguineensis). Food Sci. Tech. (Campinas), 39(1): 211-217.

Amankwah, E.A., Barimah, J., Nuamah, A. K. M., Oldham, J. H. and Nnaji, C. O. (2009).

Formulation of weaning food from fermented Maize, Rice, Soybean, and Fishmeal. Pakistan J. Nutri. 8 (11): $1747-1752$.

AOAC (2010). Association of Official Analytical Chemist, Official Methods of Analysis,

$19^{\text {th }}$ edition, Washington, D.C., USA, pp. 418421.

Asuquo, J. E., Etim, E. E., Ukpong, I. U. and Etuk, S. E. (2012). Extraction, characterization and fatty acid profile of Pogaoleosaoil. Int. J. Modern Analy. Sep. Sci. 1(1): 23-30.

Atinafu, D. G. and Bedemo, B. (2011). Estimation of total free fatty acid and cholesterol content in some commercial edible oils in Ethiopia, Bahir DAR. J. of Cereals and Oil Seeds, 2:71-76.

Choe, E. and David, B. M. (2006). Mechanisms and Factors for Edible Oil Oxidation.

Comprehensive Rev. Food Sci. Food Safety, 5: 169-186.

Codex Alimentarius Commission (2011). Codex Alimentarius Commission/FAO/WHO foodstandards. Standard for named vegetable oils. CODEX-STAN 210. (Amended), Ed.

FAO/WHO.

Dian, N. L. H. M., Hamid, R. A., Kanagaratinam, S., Isa, W. R. A., Hassim, N. A. M., Ismail, N. H., Omar, Z. and Sahri, M. M. (2017). Palm oil and palm kernel oil: Versatileingredients for food applications. J. of Oil Palm Res. 29(4): 487 - 511.

Falade, A. O., Oboh, G. and Okoh, A. I. (2017). Potential health implications of the consumption of thermally-oxidized cooking oils-a review. Polish J. Food Nutr. Sci. 67(2): 95-105.

Gayas, B. and Kaur, G. (2017). Novel oil extraction methods in food industry: A review. J. of Oilseed Brassica, 8(1): 1-11.

Gupta, M. K. (2002). Sunflower oil. In: Gunstone, F. D., ed., Vegetable oilsin food technology: Composition, properties and uses. Wiley-Blackwell, UK, pp. 125-156.

Hoekman, S. K., Broch, A., Robbins, C., Ceniceros, E. and Natarajan, M. (2012). Review of biodiesel composition, properties, and specifications. Renew. Sustainable Energy Review, 16, 143-169.

Hu, M. and Jacobsen, C. (2016). Oxidative Stability and shelf life of foods containing oils and fats. AOCS Press, San Diego, CA pp 3.

Ikhuoria, E. U. and Maliki, M. (2007). Characterization of avocado pear (Persea Americana) and Africa pear (Dacryodes edulis) extracts. Afr. J. Biotech. 7: 950954.

Isaac, I. O. and Ekpa, O. D. (2009). Minerals and anti-nutrients in two varieties of Dacryodes edulis. J. Food Tech. 7(4): 106-110.

Maszewska, M., Florowska, A., Dluzewska, E., Wroniak, M., Marciniak-Lukasiak, K. and

Zbikowska, A. (2018). Oxidation stability of selected edible oils. Molecules, 23: 2-12.

Musa, M., Sulaiman, A. U., Bello, I., Itumoh, J. E., Bello, K., Bello, A. M. and Arzika, A.T. (2012). Physicochemical properties of some commercial groundnut oil products sold in Sokoto metropolis, North West, Nigeria. J. of Biological Sci. Bioconservation, 4: 38-45.

Nayak, P. K., Dash, U., Rayaguru, K. and Krishnan, K. R. (2015). Physio-chemical changes during repeated frying of cooked oil: A review. J. FoodBiochem.,5(2):1-

20.

Nicholes, D. S., Jordan, T. B. and Kerr, N. (2011). The nomenclature and structure of lipids In: Sikorski, Z. E. and Kolakowska, A. Chemical, biological and functional aspects of food lipids. Boca Raton: CRC Press. Pp 31-51. 
Nwosuagwu, U. H., Onuegbu, C. N. and Nkwoala, C. C. (2009). The chemical properties of African pear pulp at different stages of fruit development. Int. NGO Journal. 4(9): 380-385.

Okeke, E. C., Eneobong, H. N., Uzuegbunam, A. O., Ozioko, A. and Kuhnlein, H. (2008). Igbo traditional food systems: Documentation, uses and research needs. Pakistan Journal of Nutrition, 7(2): 365-376.

Onuegbu, N. C., Nwuka, M. U., Ojukwu, M. and Kabuo, N. O. (2016). Nutritional properties of African pear seed and performance of defatted cake in poultry feed formulation. J. Animal Res. Nutr. 1(2): 1-3.

Pandurangan, M. K., Murugesan, S. and Gajivaradhan, P. (2012). Physico-chemical properties of groundnut oil and their blends with other vegetable oils. J. Chem.

Pharmaceutical Res. 6(8): 60-66.

Sofowora, L. (2008). Medicinal plants and Traditional medicine in Africa. Spectrum Books Ltd, Ibadan, Nigeria, Pp 289-291.

SPSS (2018). Statistical package for the social sciences. Guild for personal computers, version 22.0 Edition, Chicago. 